УДК 304.5; 327

\title{
DOI 10.18522/2227-8656.2020.2.5
}

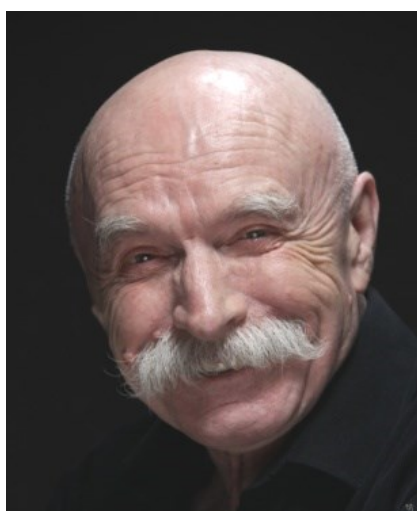

АНАЛИЗ БЮРОКРАТИИ: ОБЩАЯ МАТРИЦА И ПРОБЛЕМА

РОССИЙСКОЙ И ЕГИПЕТСКОЙ СПЕЦИФИКИ

\section{Макаренко Виктор Павлович}

Доктор политических наук, доктор философских наук, профессор, заслуженный деятель науки РФ, директор Центра политической концептологии, Высшая школа бизнеса, Южный федеральный университет, г. Ростов-на-Дону, Россия, e-mail: Vpmakar1985@gmail.com

\section{Халед Рефаат}

\section{Кемалэльдин Бадави}

Аспирант, кафедра теоретической и прикладной политологии, Институт философии и социально-политических наук, Южный федеральный университет, г. Ростов-на-Дону, Россия, e-mail: refat1968@list.ru

В статье показано, что современная матрица анализа бюрократии включает множество тем и аспектов, позволяющих изучать феномен бюрократии в его взаимосвязях со всеми сферами социальной действительно-

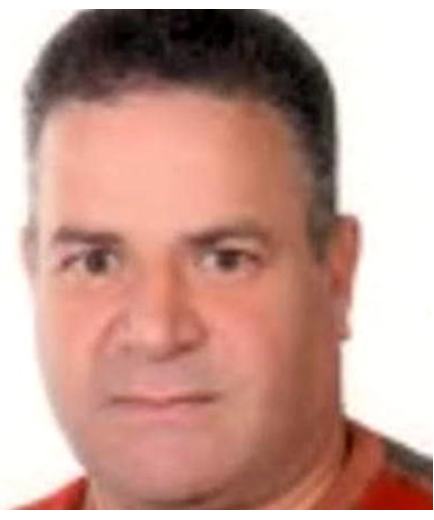

ANALYSIS

OF THE BUREAUCRACY: GENERAL MATRIX AND THE PROBLEM OF RUSSIAN AND EGYPTIAN SPECIFICITY

\author{
Viktor P. Makarenko \\ Doctor of Philosophical and Political \\ Sciences, Professor, Honored Worker \\ of Science, Director of Center \\ of Political Conceptology, \\ Higher School of Business, \\ Sothern Federal University, \\ Rostov-on-Don, Russia, \\ e-mail: Vpmakar1985@gmail.com
}

Khaled Refaat Kemaleldin Badawi

Postgraduate Student, Department of Theoretical and Applied Political Science, Institute of Philosophy and Socio-Political Sciences, Southern Federal University, Rostov-on-Don, Russia, e-mail: refat1968@list.ru

The article shows that the modern matrix of bureaucracy analysis includes many topics and aspects that allow us to study the phenomenon of bureaucracy in its interrelations with all spheres of social reality and politics. 
сти и политики. Главный интерес государственной бюрократии в любых странах (включая Россию и Египет) состоит в коллективном упрочении собственных позиций. Этот интерес связывает все уровни бюрократии и не меняется при демократическом устройстве государства.

Революции $\mathrm{XX}$ в. в странах второго мира не смогли реализовать программы преодоления бюрократии, хотя и пытались сломать государственную машину. В период перестройки в СССР был поставлен ряд крупных теоретических и практических проблем, ни одна из которых в России не решена. Революция 1952 г. превратила Египет в социалистическую республику и одновременно привела к реанимации древней системы управления страной. В современной ситуации в Египте и России склоняются к предпочтению модели К. Виттфогеля другим традициям исследования бюрократии. Для развития данной модели предлагается использовать когнитивные инновации ростовской политологической школы.
The main interest of the state bureaucracy in any country (including Russia and Egypt) is the collective consolidation of its own positions. This interest connects all levels of bureaucracy, and does not change under the democratic structure of the state. The revolution of the $20^{\text {th }}$ century in the countries of the second world could not implement programs to overcome the bureaucracy, although they tried to break the state machine. During the period of "perestroika", a number of major theoretical and practical problems were posed in the USSR, none of which have been resolved in Russia. The 1952 revolution turned Egypt into a socialist republic and at the same time led to the reanimation of the ancient system of governing the country. The current situation in Egypt and in Russia leads to the preference of the model of $\mathrm{K}$. Wittfogel to other traditions of the bureaucracy's study. To develop this model, it is proposed to use the cognitive innovations of the Rostov Political Science School.

Keywords: bureaucracy; Egypt; Russia; Karl Wittfogel; Rostov Political Science School.

Ключевые слова: бюрократия; Египет; литологическая школа.

В политической науке феномен бюрократии рассматривается в рамках общих проблем политических институтов, политических институтов с позиций рационального выбора и права, сравнительной политологии, политической теории, прошлого и будущего социальной политики и управления, политической экономии (Политическая наука ..., 1999. С. 174-183, 186-193, 199, 209-211, 470, 613-619). Каждая из этих проблем дробится на конкретные темы. Но в целом современная матрица анализа бюрократии включает исторические, антропологические, юридические, социологические, организационно-управленческие, экономические, политические, теоретические и идеологические аспекты. При этом современные идеологии (особенно марксизм, социализм, коммунитаризм) полагают тему бюрократии центральной для всех социальных наук (Макаренко, 2000. C. 327-333).

Мы тоже считаем эту тему центральной для России и Египта. Но в указанном тематическом многообразии подчеркнем констатации: бюрократия есть необходимый элемент становления и функциониро- 
вания политических институтов западных стран; применение для ее анализа веберовской модели «бюрократ-политик» и теории рационального выбора; согласие большинства ученых с тем, что даже в государствах welfare state бюрократия стремится ослабить демократию и усилить собственное господство.

Поэтому уже в 1930-е гг. ученые отмечали важность изучения бюрократии при описании того, «кто, что, где и сколько» получает от правительства (в соответствии с формулой Г. Лассуэлла). В 1980-е гг. такой подход назвали «бюрократией низового уровня». Доказано, что даже самые мелкие клерки обладают большой властью над людьми. Бюрократические организации государства - это множество заинтересованных индивидов, которые вступают (или не вступают) в коалиции с политиками не по причине собственных политических убеждений (которых обычно у чиновников нет), а из-за стремления к коллективному упрочению собственных позиций. Таков главный интерес государственной бюрократии. Он не меняется и при демократическом устройстве государства.

С институциональной точки зрения бюрократия определяется как монопольный продавец услуг, обладающий скрытой информацией об их стоимости. В этом контексте сформулированы параметры институционального выбора, которые одновременно образуют объекты исследования: уровень делегирования права на принятие решений (с учетом степени законодательной неопределенности); структура власти любой бюрократической организации (способы назначения руководящих кадров, степень юридической независимости каждого бюрократического органа и его сотрудников от законодательных и юридических органов); правила определения процедур, которые должны следовать за административным принятием решений (включая право членов законодательных органов власти принимать участие в административном процессе); характер и уровень осуществления законодательного контроля и возможность использования поощрений и санкций ex post, а также правила руководства распределением и использованием капитала и рабочей силы.

В заключение этого внушительного списка авторы добавляют: «Возможности систематической исследовательской работы в этом направлении еще далеко не исчерпаны» (Политическая наука ... , 1999. С. 641). Иначе говоря, институциональный подход позволяет соединить общую теорию бюрократии с анализом низового уровня бюрократии, включая каждого конкретного чиновника. 
Общая ситуация такова: даже в самой демократической стране мира главный интерес любого чиновника состоит в коллективном упрочении собственных позиций. Отсюда вытекает, что к каждому клерку должен быть приставлен свой исследователь, законодатель, полицейский, судья, политик и палач, чтобы в миллиардах управленческих ситуаций обеспечить приоритет интересов гражданина над интересами чиновника и тем самым решить проблему бюрократии. Утопичность такой перспективы не вызывает сомнений. Значит, даже демократическая политическая система не в состоянии устранить господство чиновника над гражданином.

Что же тогда сказать о странах второго мира, в которых политические институты обычно связаны с коррупцией, производством, обменом и революциями? - таков исходный вопрос статьи. Наша попытка ответа на него определяет поле исследования, которое мы ограничиваем Египтом и Россией по следующим причинам: обе страны принадлежат ко второму миру; Египет в настоящее время находится в ситуации выбора между бюрократией и теократией; традиция симфонии церкви и государства тоже сильна в России; в обеих странах в XX в. произошли революции, которые не смогли преодолеть бюрократическую систему управления (Ханна, 2010).

Например, Октябрьская революция в России осуществлялась в надежде В.И. Ленина на то, что будущее пролетарское государство решит проблему бюрократии окончательно и бесповоротно путем реализации главных принципов революционно-демократической диктатуры: жалованье чиновника не должно превышать зарплату рабочего; над всем управленческим аппаратом частных предприятий и государственных учреждений должен быть установлен революционнодемократический контроль рабочего класса и крестьянства; весь управленческий аппарат должен регулярно сменяться снизу доверху; гарантией перечисленных мер является всеобщее вооружение народа (Макаренко, 1987. С. 128-182).

Однако на всем протяжении существования СССР его политическое руководство не смогло реализовать программу, которая намечена в работе В.И. Ленина «Государство и революция». Правда, Ленин еще при жизни пытался разобраться в причинах собственной неудачи. При Сталине лозунг борьбы с бюрократизмом окончательно превратился в фигуру речи для обслуживания репрессий в отношении лиц и целых организаций (включая бывших революционеров), неугодных вершине власти (Юнге, 2015). 
Даже в период перестройки в СССР борьба с бюрократизмом превратилась в очередную политическую кампанию, которая не привела к решению проблемы. Однако в научных дискуссиях 1980-х гг. был поставлен ряд серьезных теоретических и практических проблем. Например, в 1989 г. в СССР был опубликован классический труд С.Н. Паркинсона о бюрократии. В послесловии к этой работе известные социологи Л.Г. Ионин и О.И. Шкаратан обобщили множество фактов, феноменов и тенденций, накопившихся на протяжении существования СССР:

- веберовский идеальный тип бюрократии не может использоваться для анализа советской бюрократии;

- надо выяснить принципиальное отличие подхода Маркса к анализу и оценке бюрократии от веберовского и либерального;

- советская бюрократия владела собственностью, обществом, средствами производства и человеческой жизнью;

- она функционировала так, что при этом не работали ни законы рынка, ни государственные законы, а царил произвол, облеченный в одежды «общественной целесообразности»;

- необходимо выработать глобально-исторический подход к анализу бюрократии;

- советские ученые не раз пытались всерьез обсудить поставленную К. Марксом проблему азиатского способа производства (АСП), в котором бюрократия занимает господствующее положение, из-за чего Маркс определял эту систему как восточный деспотизм;

- но эти дискуссии при Сталине кончались репрессиями дискутантов, а в конце 1960-х гг. - нелепыми обвинениями в адрес сторонников существования АСП и административно-волевым прекращением дискуссии;

- строительство социализма в России на деле обернулось повторением и усилением всех трагедий эпохи строительства капитализма;

- необходимо обосновать концепт антибюрократической революции на всем земном шаре и в каждой отдельной стране;

- законы Паркинсона надо уточнять применительно к месту и времени;

- при анализе советского общества важно применять закон вакуума Паркинсона (действие расширяется, чтобы заполнить пустоту, созданную промахами и ошибками политических руководителей);

- задача преодоления бюрократии является многопоколенной;

- советские граждане и общество в целом не имели никаких возможностей влиять на выработку финансовой политики государства;

- полное обезличивание сумм на различные «государственные дела» есть результат системы бюрократического управления обществом;

- уверенное в себе беззаконие - типичная характеристика СССР; 
- заработная плата в СССР устанавливалась не за проделанную работу, а за точку, которую занимал на шкале должностей индивид;

- чиновнику в СССР принадлежало неписаное право давать людям жить или убивать их;

- распределение в СССР осуществлялось по законам сословного общества;

- большинство людей в получении благ зависели не от успешности своего труда, а от своего статуса и воли вышестоящих лиц;

- поэтому СССР не смог уйти от капитализма, антиподом которого он хотел стать;

- СССР отличался от других стран каналами мобильности, которые объяснялись спецификой бюрократической системы;

- стремление к власти в данной системе было одним из наиболее порочных человеческих и социальных свойств;

- секретность - одно из могущественных орудий бюрократии, которая несет с собой тысячи социальных зол (Ионин, 1989. С. 426-447).

Эти констатации сделаны более 30 лет тому назад. Но невозможно утверждать, что они устарели - в России ситуация усугубилась (Российское государство ..., 2007; Клямкин, 2005). Что касается их применения к ситуации в Египте, то вначале обратимся к историческим фактам. В Египте возникла одна из самых древних систем бюрократии, направленная на регулирование притоков и оттоков воды в Ниле для производства продуктов сельского хозяйства. В первые годы христианской эры Египет попал под римское господство, а затем входил в состав Османской империи, генезис и распад которой имеют сходство с генезисом и распадом Российской империи ${ }^{1}$. Главной причиной успеха и упадка обеих империй была централизация государственного управления: «очень многое зависело от способностей правителя, оказавшегося у власти по наследственному принципу, в то время как память о золотом веке препятствовала проведению реформ» (Ливен, 2007. С. 250). Иначе говоря, традиция единоличного правления вкупе с идеей о существовании золотого века в

${ }^{1}$ Сходство состояло в следующем: появление на периферии огромных территорий и цивилизаций, над которыми они впоследствии установили свое господство; одновременное обращение в христианство и в ислам (Х в.); одновременное заселение будущего центра имперской территории (XI в.); преобладание в религиозности населения на протяжении всего Средневековья смеси язычества с исламом (христианством) и вытекающее отсюда противоречие между верой городских религиозных лидеров и религиозностью народа; генезис первых правителей из среды военачальников, основой власти которых было насилие, обеспечивающее сторонников добычей, землей, престижем и чувством исполненного религиозного долга в войнах с инаковерующими; наследование родовых земель первыми царствующими династиями, одним наследником (с XIV в.); превращение военачальников в монархов, которые создали государственные институты для многовековой поддержки собственного владычества; квалификация кавалерии вплоть до XVI в. как основной части армии, которая получала от монарха земли в награду за военную службу; развитие в регионах, прежде контролируемых наследниками великого хана (Ливен, 2007. С. 223-225). 
прошлом и вытекающая отсюда блокировка реформ - значимый пункт при сопоставлении бюрократий Египта и России.

В частности, крушение Османской империи привело к тому, что ее арабская часть (в состав которой входил Египет) была поделена между Англией и Францией. Англия после 1881 г. обещала независимость Египту 60 раз и к тому же была должна Египту 400 млн фунтов стерлингов. В 1952 г. в Египте произошла революция, руководителем стал полковник Гамаль Абдель Насер. В течение двух лет после революции Египет и Великобритания урегулировали свои разногласия (Кальвокоресси, 2003. С. 449, 462).

Затем Египет стремился восстановить союз с Суданом, поскольку воды Нила имели для него жизненно важное значение, а мечта о целостности долины Нила жила в сознании египтян со времен древних фараонов. Строительство Асуанской плотины было направлено на осуществление экономических и социальных преобразований в Египте, поскольку это позволяло увеличить площади пахотных земель на 860 тыс. га, сделать Нил судоходным на всем протяжении - к югу до границы с Суданом - и наладить производство электроэнергии для промышленных предприятий, которые могли бы обеспечить быстрорастущее население средствами к существованию (Кальвокоресси, 2003. C. 464-468).

Революция 1952 г. превратила Египет в социалистическую республику и одновременно связала ее с древней проблемой государственнобюрократического управления сельским хозяйством, которая решалась в условиях конфликта между внешней и внутренней политикой Египта ${ }^{1}$. На протяжении второй половины XX в. в Египте предпринимались попытки перестроить одну из самых древних систем бюрократического управления государством. Однако они не увенчались успехом. Наоборот, привели к революции 2011 г. В настоящее время процесс перестройки бюрократического управления в Египте продолжается.

1 «Насеру было некогда заниматься внутренними делами. Его внешняя политика сделала экономические проблемы Египта непреодолимыми. Организаторы революции всегда стремились создать более сильную, более эффективную и лучше оснащенную армию, чем армия Фарука. Эта задача приобретала все более актуальный характер ввиду необходимости защищать страну от Израиля, а революцию - от Ирака Нури и его британских покровителей. Поэтому в поисках оружия и средств на его закупку Насер вначале увеличил долю оборонных расходов Египта в национальном доходе страны сверх всякой меры, а затем был вынужден занимать суммы, которые Египет едва ли мог вернуть. Помощь и ресурсы, которые можно было бы направить на цели развития, использовались для дефицита внешнего платежного баланса, рост которого с 1961 г. достиг внушающих тревогу масштабов. Война в Йемене усугубила положение. Продолжавшаяся война с Израилем лишала Египет американской помощи и бесплатного продовольствия. К моменту смерти Насера египтяне едва ли жили лучше в материальном отношении, чем за 18 лет до этого (хотя условия жизни в городах несколько улучшились), а сам Египет оказался в черных списках Запада и заложником СССР» (Кальвокоресси, 2003. С. 491). 
Отсюда вытекает следующая констатация: революция может привести к реанимации древней системы управления страной. Рассмотрим горизонт выбора при интеграции частных ответов в цепь проблем.

В мировой литературе тема бюрократии и бюрократического управления государством традиционно связывается с именем М. Вебера. Он создал типологию господства, в составе которого легальное господство с бюрократическим штабом управления связывается со становлением «рационального государства» (Вебер, 2016. С. 256-264). В основном в современной египетской и российской научной литературы теория бюрократии М. Вебера считается классической.

Однако в Советском Союзе тема бюрократии как предмет научных исследований принадлежала к идеологическим и политическим табу. Особенно после того, как Л.Д. Троцкий в 1928 г. написал статью «О философских тенденциях бюрократизма», а затем ввел концепт сталинской бюрократии для объяснения процесса перерождения советской власти в термидорианскую диктатуру (Троцкий, 1928, 2011). Такой подход позволял ему рассматривать партийно-государственный аппарат СССР как сословие, а не класс.

Но эта позиция уже в 1920-е гг. начала оспариваться марксистом и членом Коммунистической партии Германии К. Виттфогелем. Он одним из первых начал развивать концепцию восточного деспотизма К. Маркса на примере Древнего Египта: «Власть фараонов была настолько всеобъемлющей, что частному независимому ремесленному производству не удалось добиться значительного прогресса, а независимая профессиональная торговля добилась еще меньшего в течение длительного периода этой эпохи. Преобладание государственной торговли и вес управляемого правительством производства вместе с господством регулируемой государством земельной собственности создали и поддерживали в фараонском Египте исторически и институционально важный вариант простой модели гидравлической собственности и гидравлического общества» (Виттфогель, 2017) ${ }^{1}$.

На основе изучения процессов государственного регулирования притоков воды главных рек Египта и Китая и связанного с данными процессами применения массового подневольного труда К. Виттфогель квалифицировал египетскую и китайскую бюрократию как класс, возникающий в рамках АСП, а также предложил применить то же определение к государственному аппарату царской России и Советского Союза. Поэтому объяснение египетской и российской (совет-

\footnotetext{
${ }^{1}$ Виттфогель K. Деспотизм Востока. Сравнительное исследование тотальной власти. Фараонский Египет. URL: http://samlib.ru/s/strahow_a_a/wittfogel-oriental-despotism.shtml\#7-f-4-c.
} 
ской) бюрократии уже в период между Первой и Второй мировыми войнами приобрело политическую остроту и актуальность.

Труд К. Виттфогеля «Восточный деспотизм» в современной политической науке квалифицируется как одна из главных книг XX в., в которой осуществлен синтез сравнительной истории и сравнительной политологии на основе пересечения гибридных отраслей знания: исторической социологии, социальной истории, экономической истории, культурной истории, асинхронных сопоставлений (Политическая наука ..., 1999. С. 139). Иначе говоря, этот труд обладает реальным междисциплинарным значением, причем указанные сферы знания в исполнении К. Виттфогеля непосредственно связаны определенной политической оценкой.

Теория гидравлического государства К. Виттфогеля позволяет связать ситуацию в Египте с ситуацией в России, поскольку для обеих стран отношения власти-собственности и вытекающий отсюда властецентризм являются типичными. На рубеже XX - XXI вв. произошла реанимация данной теории как способа объяснения властисобственности и бюрократии. В мировой науке сложились тенденции полного или частичного согласия с данной теорией. Она до сих пор востребована в теоретических, политических и идеологических целях. Окончательный ответ о мере ее истинности или ложности возможен в процессе изучения специфики гидравлического хозяйства, процессов государствообразования и генезиса бюрократии всех государств. Данную теорию можно поместить в состав общей проблемы политики и природы, надежными способами решения которой не располагает ни одно государство мира. Оценка теории К. Виттфогеля может осуществляться на фоне интеграции современного востоковедения со становлением критического марксизма в России и необходимостью разработки контридеологии, поскольку в российских СМИ реанимируется инструментарий холодной войны.

Теория гидравлического государства удовлетворяет критерию спорности всех политологических понятий и концепций. Она сохранила свой дискуссионный потенциал. Об этом свидетельствуют разработанный К. Виттфогелем понятийный аппарат модели многонаправленной социальной эволюции, онтологический закон гидравлического общества, неопределенность международных и страновых критериев для установления минимума и максимума рациональности властвующих элит, трагичность всей предшествующей истории, универсальность перспективы бюрократического господства в современном мире, проблематичность категориального аппарата (единичные, особые и 
всеобщие категории) социальных наук для анализа бюрократии как составной части модели многонаправленной социальной эволюции. Всемирно-историческая трагедия состоит в том, что со времени появления гидравлического общества бюрократия воспроизводится на протяжении всей истории. Теория К. Виттфогеля образует эвристическую предпосылку современной аналитики государственных интересов и правительности и может служить введением в востоковедческие споры (Халед Рефаат Кемалэльдин Бадави, 2020).

Поэтому возникает вопрос: кому оказать предпочтение при анализе египетской и советской бюрократии: М. Веберу или К. Виттфогелю? Особенно с учетом того, что после Второй мировой войны советский коммунизм превратился в мировую систему ${ }^{1}$ : «Повсеместной была вера, что заря человечества взошла вместе с русской революцией» (Милош, 2014. С. 274-275).

Но вера начала шататься примерно в то же время. Теперь уже сами представители партийно-государственного аппарата (М. Джилас, М. Восленский и др.) доказывали, что правящие группы Советского Союза и других «стран народной демократии» являются новым привилегированным, господствующим и эксплуататорским классом (Джилас, 1961; Восленский, 2005). Эти работы вошли во всеобщий оборот в СССР только в период перестройки, когда обострилась дискуссия о природе бюрократии. На протяжении длительного времени советские идеологи доказывали, что бюрократия классом не является.

Фон дискуссии начал складываться в 1960-1980-е гг., когда были опубликованы труды советских ученых, которые заложили основы ряда направлений анализа бюрократии. Они частично резюмированы в историографической концепции Л.Н. Мазур: теоретико-социологические исследования, направленные на осмысление самого феномена бюрократии и ее роли в обществе; история государственного управления, изучающая становление и эволюцию государственных институтов; история чиновничества как социального ядра бюрократии; изучение исторических типов, социальной структуры бюрократии, ее групповых характеристик. Примечательно, что Л.Н. Мазур оперирует понятиями АСП и аграрной бюрократии в отношении Российской империи, СССР и современной России. Но даже не упоминает при этом К. Виттфогеля (Мазур, 2013. S. 597-621).

${ }^{1}$ Термин «коммунизм» в этом и всех остальных случаях (если это специально не оговаривается) используется в том смысле, который придал ему А.А. Зиновьев: никакого реального (а не книжного) коммунизма, кроме советского, больше не существовало (Зиновьев, 2012). 
Мы назвали концепцию Л.Н. Мазур частичной потому, что за пределами ее внимания осталась целая школа по исследованию бюрократии, власти и политики, формировавшаяся в Ростовском государственном (с 2006 г. - Южном федеральном) университете на протяжении 1980-2010-х гг. В этой школе с 1980-х гг. развивается марксовский (а не веберовский) подход к анализу классовой природы бюрократии. В рамках данного подхода бюрократия определяется как социальный организм-паразит на всем протяжении своего исторического существования, отражение социальных противоречий и конфликтов и материализация политико-управленческого отчуждения. Кроме того, бюрократия изучается не как часть организационно-управленческих процессов (что типично для большинства работ по теме бюрократии), а во взаимосвязи с проблемами политической оппозиции и легитимности, каждой из которых дается операциональное определение (Макаренко, 2019).

Для анализа проблемы бюрократии в ростовской политологической школе создано несколько когнитивных инноваций:

- концепт троевластия используется для объяснения генезиса экономических, политических, идеологических и цивилизационных аспектов русской власти-собственности (Макаренко, 2010. С. 169);

- концепт «сжирубешенства» используется для анализа связи современной русской власти и бюрократического государства со всеми сферами социальной и политической жизни России на фоне вопиющего социального неравенства (Макаренко, 2016);

- концепт научно-технической контрреволючии реконструирован из работ М.К. Петрова и применяется для описания сферы различных моделей господства (колониально-имперского, революционнобюрократического и самодержавно-бюрократического) правительств над всей системой науки как социального института (Макаренко, 2011);

- концепт интеллектуально-политических мод используется для анализа и критики всех идеологических продуктов главных звеньев государственной машины России (Макаренко, 2009);

- политическая бюрократия выделяется в особую сферу исследований со своей проблематикой и структурой (Макаренко, 2018).

Для методологического обоснования указанных когнитивных инноваций разработана политическая концептология - междисциплинарный интегративный подход к анализу, пониманию и моделированию политической реальности и политического мышления, который включает пересмотр всех основных понятий политического словаря с целью обнаружения их ложности или дискуссионности в условиях современной России. Среди прочего показано, что на фоне конкурирую- 
щих концепций междисциплинарности, анализа и понимания методологический выбор исследователя всегда переплетен с политическим. Пространство этого выбора сводится к альтернативе предельная ангажированность - максимальное дистанцирование. Предельная ангажированность выражается в социальном и познавательном перфекционизме. Для его обоснования могут использоваться как повседневный сервилизм, так и рафинированные детерминистские схемы, включая весь корпус социогуманитарных знаний при описании социальной и политической истории своего народа и страны. Эти процедуры и связанные с ними познавательные схемы квалифицируются как варианты традиционализма, экономикоцентризма, кратоцентризма и идеократии в региональном, национально-государственном, цивилизационном и мировом измерении (Макаренко, 2002, 2005, 2011). Если исследователь попадает в плен данных схем, он не может реализовать когнитивную свободу, без которой невозможно обеспечить адекватное отражение действительности с учетом извечной противоположности между истиной и политикой (Арендт, 2014. С. 334-389).

Таким образом, в ростовской политологической школе методология анализа и теория бюрократии создаются посредством реконструкции исследовательской практики К. Маркса в целях противопоставления его концепции бюрократии веберовской традиции ее анализа и всей политической практике людей, называвших себя марксистамиленинцами, в процессе становления, развития и краха ленинскосталинской диктатуры в СССР и ее влияния на социальнополитические процессы в современной России. Это фундаментальное исследование образует составную часть критического (неортодоксального) марксизма, который противостоит любым (особенно советским) формам политического и идеологического использования теории Маркса (Маркс против марксизма ..., 2017). В литературе уже отмечалось, что такой подход к трудам Маркса является оригинальной авторской концепцией - предельным случаем академической свободы в России - и значительно отличается от теории М. Вебера, которую невозможно напрямую применять к анализу российской реальности (Тимофеева, 2015. С. 178-184; Олейник, 2019).

Отметим, что такой подход в значительной степени совпадает с современной ситуацией в Египте. Египетские публицисты, политики и ученые сформировали значительный интеллектуальный ресурс для обсуждения проблем, связанных с ростом вмешательства бюрократии в социальную жизнь. К ним относятся: 
- географические и социальные условия генезиса египетской бюрократии;

- связь системы образования с подготовкой бюрократии;

- определение социальной болезни как меры влияния бюрократии на общество;

- сопротивление бюрократии любым политическим и административным реформам;

- квалификация бюрократического управления государством как причины постоянного политического кризиса страны;

- специфика отношения между правительством и бюрократией;

- квалификация политических реформ как бесплодных при господстве бюрократии;

- отношение между государственным управлением в Египте и современной западной теорией управления;

- феномен бюрократического равенства зарплаты и исключения наказаний для всех государственных служащих;

- выявление абсолютной и относительной пропорции между числом бюрократии и населения в Египте по сравнению с другими странами;

- поиск необходимого и оптимального числа центральных и местных государственных учреждений;

- квалификация недостатков бюрократии как следствия меры централизации управления страной;

- фиксация отрицательной связи между бюрократическим управлением государством и достижением политических целей;

- анализ революций с точки зрения отношения между политиками и бюрократией;

- изучение поведения бюрократии в революционных ситуациях;

- определение бюрократии как противника любых институциональных изменений;

- поиск меры эффективности привлечения иностранных экспертов для решения проблемы бюрократии в стране;

- критика основных положений теории рациональной бюрократии М. Вебера;

- квалификация причин воспроизводства бюрократии как следствия применения к ним веберианского подхода;

- установление общих, особенных и единичных свойств бюрократии в стране;

- учет отношения между законами, должностными инструкциями и реальным поведением чиновников; 
- определение сути бюрократической манипуляции поведением граждан;

- определение проблемы отбора чиновников на государственные посты как меры политического противодействия любым кровнородственным, земляческим и клановым отношениям;

- установление меры и критериев документооборота в каждой стране;

- анализ отношения между генезисом политических лидеров, выработкой ими программ политических изменений и их реальной деятельности по созданию условий для политических преобразований (Халед Рефаат Кемалэльдин Бадави, 2020).

Нетрудно убедиться, что перечисленные результаты обсуждения проблемы бюрократии в Египте среди египетских специалистов в значительной степени совпадают с итогами обсуждения данной проблемы в России. Все это создает обширную исследовательскую и политическую панораму, для анализа которой вполне можно использовать когнитивные инновации ростовской политологической школы для сравнительного анализа российской и египетской бюрократии.

\section{Резюме}

Современная матрица анализа бюрократии включает множество тем и аспектов, позволяющих изучать феномен бюрократии в его взаимосвязях со всеми сферами социальной действительности и политики. Даже в государствах welfare state бюрократия стремится ослабить демократию и усилить собственное господство. Главный интерес государственной бюрократии состоит в коллективном упрочении собственных позиций. Этот интерес связывает все уровни бюрократии. Он не меняется и при демократическом устройстве государства.

Институт бюрократии есть монопольный продавец услуг, обладающий скрытой информацией об их стоимости. В этом контексте параметры институционального выбора образуют объекты исследования, которые до сих пор не исчерпаны. Институциональный подход соединяет теорию бюрократии с анализом ее низового уровня. Приоритет интересов гражданина над интересами чиновника до сих пор не обеспечен даже в демократических странах.

Революции XX в. в странах второго мира не смогли реализовать программы преодоления бюрократии, хотя и пытались сломать государственную машину. В период перестройки в СССР был поставлен ряд крупных теоретических и практических проблем, ни одна из которых тоже не решена. Революция 1952 г. превратила Египет в социали- 
стическую республику и одновременно привела к реанимации древней системы управления страной. В целом в современной ситуации в Египте и России склоняются к предпочтению модели К. Виттфогеля другим традициям исследования бюрократии. Для развития данной модели можно использовать когнитивные инновации ростовской школы.

\section{Литература}

Арендт X. Между прошлым и будущим. Восемь упражнений в политической мысли / пер. с англ. и нем. Д. Аронсона. М. : Изд-во Ин-та Гайдара, 2014.

Вебер M. Хозяйство и общество: очерки понимающей социологии : в 4 т. / сост., общ. ред. и предисл. Л.Г. Ионина. М.: Изд. дом Высшей школы экономики, 2016. T. 1.

Виттфогель К. Деспотизм Востока. Сравнительное исследование тотальной власти. Фараонский Египет. Режим доступа: http://samlib.ru/s/strahow a a/wittfogeloriental-despotism.shtml\#7-f-4-c.

Восленский М.С. Номенклатура: господствующий класс Советского Союза. М.: Захаров, 2005.

Джсилас М. Новый класс. Нью-Йорк: Изд-во Ф.А. Прегера, 1961. Режим доступа: https://vtoraya-literatura.com/pdf/dzhilas novyj_klass_1961_text.pdf.

Зиновьев $A . \bar{A}$. Коммунизм как реальность. Пара беллум. М.: АСТ, 2012.

Ионин Л., Шкаратан О. Паркинсон и бюрократы (послесловие-диалог) // Паркинсон С.Н. Законы Паркинсона : сб. / пер. с англ.; сост. и авт. предисл. В.С. Муравьев. М.: Прогресс, 1989.

Кальвокоресси П. Мировая политика 1945-2000 : в 2 кн. : пер. с англ. М.: Междунар. отношения, 2003. Кн. 1.

Клямкин И., Кутковец Т. Как нас учат любить Родину? Режим доступа: https:// www.democracy.ru/article.php?id= 1136.

Ливен Д. Российская империя и ее враги с XVI века до наших дней / пер. с англ. А. Козлика и А. Платонова. М.: Европа, 2007.

Мазур Л.Н. Становление и эволюция

\section{References}

Arendt, H. (2014). Between the Past and the Future. Eight exercises in political thought. Trans. from English and Germ. D. Aronson. M.: Izd-vo Institute Gaidar. (in Russian).

Weber, M. (2016). Economy and society: essays in understanding sociology: in 4 vol. Comp., Ed. and foreword. L.G. Ionina. M.: Izd. dom Vysshey shkoly ekonomiki, 1. (in Russian).

Wittfogel, K. Despotism of the East. Comparative study of total power. Pharaoh Egypt. Available at: http:// samlib.ru/s/ strahow a a/wittfogel-oriental-despotism. shtml\#7-f-4-c. (in Russian).

Voslensky, M.S. (2005). Nomenclature: the ruling class of the Soviet Union. M.: Zakharov. (in Russian).

Jilas, M. (1961). New Class. N.Y.: Izdvo F.A. Pregera. Available at: https:// vtoraya-literatura.com/pdf/dzhilas_novyj_ klass_1961_text.pdf. (in Russian).

Zinoviev, A.A. (2012). Communism as a reality. Para bellum. M.: AST. (in Russian).

Ionin, L., Shkaratan, O. (1989). Parkinson and bureaucrats (afterword-dialogue). In Parkinson S.N. Parkinson's Laws: a compilation. Trans. from English., comp. and auth. foreword V.S. Muraviev. M.: Progress. (in Russian).

Kalvokoressi, P. (2003). World politics 1945-2000: In 2 books. Trans. from English. M.: Mezhdunar. otnosheniya, 1. (in Russian).

Klyamkin, I., Kutkovets, T. How are we taught to love our Motherland? Available at: https://www.democracy.ru/article.php?id=11 36. (in Russian).

Liven, D. (2007). The Russian Empire and its enemies from the 16th century to the present day. Trans. from English A. Kozlik and A. Platonov. M.: Evropa. (in Russian).

Mazur, L.N. The formation and evolu- 
сельской бюрократии в России во второй половине XIX - XX вв. // Bjurokracja komunistyczna. Dzieje bjurokracji. 2013. T. 5. S. 597-621.

Макаренко В.П. Аналитическая политическая философия: очерки политической концептологии. М.: Праксис, 2002.

Макаренко В.П. Бюрократия и государство: ленинский анализ бюрократии царской России. Ростов н/Д. : Изд-во Рост. ун-та, 1987.

Макаренко В.П. Главные идеологии современности. Ростов н/Д. : Феникс, 2000.

Макаренко В.П. Насилие и политическая бюрократия. Ростов н/Д.; Таганрог : Изд-во Южн. фед. ун-та, 2018.

Макаренко В.П. Научнообывательское знание - интеллектуальнополитические моды? // Политическая концептология. 2009. № 2. Режим доступа: http://politconcept.sfedu.ru/2009.2/04.pdf.

Макаренко В.П. Научно-техническая контрреволюция: актуальность идей М.К. Петрова. Ростов н/Д. : Ростиздат, 2011.

Макаренко В.П. «Свой чужой»: концепт русской власти // Политическая концептология. 2010. №2. С.130-174.

Макаренко В.П. Политическая концептология : учеб. пособие. Ростов н/Д. : Изд-во Южн. фед. ун-та, 2011.

Макаренко В.П. Политическая концептология: обзор повестки дня. М.: Праксис, 2005.

Макаренко В.П. Русская власть и бюрократическое государство. 2-е изд., испр. и доп. Ростов н/Д. : Изд-во Южн. фед. унта, 2016.

Макаренко В.П. Собр. соч. : в 3 т. T. 1 : Вера, власть и бюрократия: критика социологии Макса Вебера. Власть и легитимность. Непобитый рекорд и проблема отношения к чемпионам. Нереализованная идея столетней давности. Ростов н/Д.; Таганрог : Изд-во Южн. фед. ун-та, 2019.

Макаренко В.П. Соб. соч. : в 3 т. Т. 2 : Бюрократия и сталбинизм. Политическая инерция: опыт рефлексии. Легитимна ли государственная служба России? Ростов tion of rural bureaucracy in Russia in the second half of the 19th -20 th centuries. Bjurokracja komunistyczna. Dzieje bjurokracji, 5, 597-621. (in Russian).

Makarenko, V.P. (2002). Analytical political philosophy: essays on political conceptology. M.: Praxis. (in Russian).

Makarenko, V.P. (1987). Bureaucracy and the state: Leninist analysis of the bureaucracy of Tsarist Russia. Rostov-on-Don: Izdvo Rost. un-ta. (in Russian).

Makarenko, V.P. (2000). The main ideologies of our time. Rostov-on-Don: Feniks. (in Russian).

Makarenko, V.P. (2018). Violence and political bureaucracy. Rostov-on-Don; Taganrog: Izd-vo Yuzh. fed. un-ta. (in Russian). Makarenko, V.P. (2009). Scientific philistine knowledge - intellectual-political modes? Politicheskaya kontseptologiya, 2. Available at: http:// politconcept.sfedu.ru/ 2009.2/04.pdf. (in Russian).

Makarenko, V.P. (2011). Scientific and technical counter-revolution: the relevance of the ideas of M.K. Petrov. Rostov-on-Don: Rostizdat. (in Russian).

Makarenko, V.P. (2010). "Us-them": the concept of Russian power. Politicheskaya kontseptologiya, 2, 130-174. (in Russian).

Makarenko, V.P. (2011). Political conceptology. Tutorial. Rostov-on-Don: Izd-vo Yuzh. fed. un-ta. (in Russian).

Makarenko, V.P. (2005). Political conceptology: an agenda review. M.: Praxis. (in Russian).

Makarenko, V.P. (2016). Russian power and a bureaucratic state. 2nd ed. and add. Rostov-on-Don: Izd-vo Yuzh. fed. un-ta. (in Russian).

Makarenko, V.P. (2019). Collected Works: in 3 vols. Vol. 1: Faith, power and bureaucracy: a criticism of Max Weber's sociology. Power and legitimacy. Unbroken record and problem attitude to the champions. Unrealized idea of a hundred years ago. Rostov-on-Don; Taganrog: Izd-vo Yuzh. fed. un-ta. (in Russian).

Makarenko, V.P. (2019). Collected Works: in 3 vols. Vol. 2: Bureaucracy and stalbinism. Political inertia: the experience of reflection. Is the civil service of Russia legit- 
н/Д.; Таганрог : Изд-во Южн. фед. ун-та, 2019.

Макаренко В.П. Собр. соч. : в 3 т. Т. 3 : Что такое троевластие? Русская власть: теоретико-социологические проблемы. Проблема общего зла: расплата за непоследовательность. Ростов н/Д.; Таганрог : Изд-во Южн. фед. ун-та, 2019.

Маркс против марксизма, марксизм против Маркса. Беседа с Валерием Подорогой о советской философии // Stasis. 2017. T. 5. № 2. С. 530-552.

Милош Ч. Азбука / пер. с польск. Н. Кузнецова. СПб. : Изд-во Ивана Лимбаxa, 2014.

Олейник А.Н. Радикальный контестатор: социология российской науки через призму анализа предельного случая // Coцис. 2019. № 7. С. 125-136.

Политическая наука: новые направления / под ред. Р. Гудина и Х.-Д. Клингеманна; науч. ред. рус. изд. Е.Б. Шестопал. М.: Вече, 1999.

Российское государство: вчера, сегодня, завтра / под общ. ред. И.М. Клямкина. М.: Новое изд-во, 2007.

Тимофеева Л.Н. Русская власть и бюрократическое государство по В.П. Макаренко // Полис. 2015. № 3.

Трочкий Л.Д. О философских тенденциях бюрократизма. Режим доступа: https:// www.marxists.org/russkij/trotsky/ 1928/philosophical_tendencies/01.htm.

Трочкий Л.Д. Сталин. Книга первая. М. : Эксмо, 2011.

Троикий Л.Д. Сталин. Книга вторая. М. : Эксмо, 2011.

Халед Рефаат Кемалэльдин Бадави. Проблема бюрократии в теории гидравлического государства : дис. ... канд. полит. наук. Ростов н/Д., 2020.

Ханна П. Второй мир / вступ. ст. В.Л. Иноземцева. М.: Европа, 2010.

Юнге М. Революционеры на пенсии. Всесоюзное общество политкаторжан и ссыльнопоселенцев. 1921-1935. М.: АИРОXXI, 2015.

\section{Поступила в редакцию}

imate? Rostov-on-Don; Taganrog: Izd-vo Yuzh. fed. un-ta. (in Russian).

Makarenko, V.P. (2019). Collected Works: in 3 vols. Vol. 3: What is a trio power? Russian power: theoretical and sociological problems. The problem of common evil: reckoning for inconsistency. Rostov-on-Don; Taganrog: Izd-vo Yuzh. fed. un-ta (in Russian).

Marx against Marxism, Marxism against Marx. Conversation with Valery Podoroga about Soviet philosophy. (2017). Stasis, 5, 2, 530-552. (in Russian).

Milos, C. (2014). Alphabet. Trans. from Polish N. Kuznetsov. SPb.: Izd-vo Ivana Limbakha. (in Russian).

Oleynik, A.N. (2019). The radical contester: the sociology of Russian science through the prism of the analysis of the limiting case. Socis, 7, 125-136. (in Russian).

Political science: new directions. (1999). In R. Gudin and H.-D. Klingemann (Eds.); scientific Russian ed. E.B. Shestopal. M.: Veche. (in Russian).

Russian state: yesterday, today, tomorrow. (2007). Under the general ed. I.M. Klyamkina. M.: Novoye izd-vo. (in Russian).

Timofeeva, L.N. (2015). Russian power and the bureaucratic state according to V.P. Makarenko. Polis, 3. (in Russian).

Trotsky, L.D. On the philosophical trends of bureaucracy. Available at: https://www.marxists.org/russkij/trotsky/192 8/philosophical_tendencies/01. (in Russian).

Trotsky, L.D. (2011). Stalin. Book one. M.: Eksmo. (in Russian).

Trotsky, L.D. (2011). Stalin. The second book. M.: Eksmo. (in Russian).

Khaled Refaat Kemaleldin Badawi. (2020). The problem of bureaucracy in the theory of the hydraulic state. (Candidate Dissertation, Southern Federal University, Rostov-on-Don). (in Russian).

Hannah, P. (2010). Second world. Entry article by V.L. Inozemtsev. M.: Yevropa. (in Russian).

Junge, M. (2015). Retired revolutionaries. All-Union society of political prisoners and exiled settlers. 1921-1935. M.: AIROXXI. (in Russian).

20 марта 2020 2. 